\title{
Does Corporate Governance Influence Enterprise Risk in India? An Analytical Study
}

Sajit Jacob*

\section{Abstract}

This paper investigates the association between Corporate Governance (CG) performance and enterprise risk in India. The study also investigates the behavior of risk under different classifications. As part of this study, Risk is estimated through a Multifactor Estimation of VaR. with Cash Value Added being used as the covariate that represents the value of the firm. This study helps to rate the progress of enterprise risk governance reforms from the point of CG performance, plan further reforms and enable investors to choose the right firms. Policy makers will know where to focus, stakeholders will recognize their roles and responsibilities with respect to risk management and management will take informed operational decisions around the policies set. Major findings of the paper are: there exists significant risk on the extreme ends of the CGPI ordinal scale, CGPI influences CVA which in turn determines enterprise risk, CVA and risk analysis finds a significant role for industrial segments. Also the number of risk free companies in these extreme segments is the least. Manufacturing and service sectors carry maximum risk.

Keywords: Corporate Governance Performance Index, Enterprise Risk, Value at Risk, Cash Value Added

\footnotetext{
* Research Scholar, Department of Commerce, Bharathiar University, Coimbatore, India; sajitjacob@rediffmail.com
} 


\section{Introduction}

Originating from Adam Smith and eventually developed by Jensen and Meckling (1976) is the concept of principal-agent conflict and the idea of monitoring the agent though it involves cost. The conflict rises with inadequate and imperfect control mechanisms among the involved parties leading to indiscipline and criminal tendencies which raise the enterprise risk that erodes the value of the corporation. While 1970s and 80s are dominated by US centric Corporate Governance (CG) studies, latter part of 90s contributions from other developed and developing countries and their experiences have enriched the literature. These studies like Shleifer and Vishny (1997) looked at effectiveness of mechanisms to assure returns to the suppliers of capital thereby raising the value of the company for the owners. But, most of these mechanisms that are centered on board structure, board behavior, board responses etc. and its effectiveness are evaluated on financial performance analysis of the firm. A series of accounting scandals leading to value crash and subsequent bankruptcy filings (Agrawal and Chadha, 2004) questions the inferences made out of many effectiveness studies. This heightened the need for finding a way to assess the influence of CG performance with a reliable financial performance indicator which reflects value of the firm.

High performance and profitability are obvious indicators of firm performance. But firms achieve performance after navigating through a variety of risks under categories such as financial, operational, market etc. If the firms end insolvent and succumb to credit risk, it erodes value of the firm and it gets directly attributed to failure of CG. Thus, CG assumes a critical role in reducing the probability of a crisis. It is the effectiveness of the internal controls that is part of CG infrastructure that acts as the Enterprise Risk Governance (ERG) mechanism. Therefore, value of a firm post managing the risk becomes a critical parameter for evaluating the effectiveness of $C G$ as well. Risk exposure of the variable that denotes value of the firm will eventually emerge as a better indicator of risk. In other words, evaluating the potential downside loss of the indicator will identify the risk of the firm. Therefore, success of risk management lies in managing that potential 16 
downside loss, from where firm will find additional value. (Damodaran 2012)

Manifestation of any risk involves a financial loss. Excess cash a firm carries will assure risk mitigation as well as will fund its possible future expansion including inorganic growth and dividend payments, thus associating itself with value of the firm. In other words, a firm's excess cash holding can act as a credible deterrence to the enterprise risk. Under such an assumption, depletion in the cash reserves itself will become the ultimate risk. (Nocco \& Stulz 2006)

Cash holding always carries a CG connection from Jensen and Mekling (1986) days, when the paper argues a possible conflict of interest between managers and stakeholders over that. Managers may prefer excess cash to be within their control so that they can bolster their private benefits, while stakeholders would prefer to get it as dividends increasing their cash flow (Dyck and Zingales 2004). In those countries where laws are inadequate to prevent expropriation, firms hold more cash as a larger buffer to protect against adverse shocks (Acemoglu, et al., 2003). CG influences corporate liquidity and provides stakeholders with opportunity to restrict agent's discretionary spending (Isshaq et al. 2009) to assure stake holders of their share and ensures reasonable cash holding, while weaker governance results in higher conflict of interest (Harford et al. 2008). Therefore, liquid assets form a parameter to investigate the implications of agency theory and thus a key proxy of CG (Myers \& Rajan 1998).

This paper measures excess cash holding in terms of Cash Value Added (CVA) as it represents the amount of net free cash generated by a company through its business operations. While these operations are well governed, cash holding becomes a planned process. In other words, governance starts adding value to operations that results in cash (Ottosson \& Weissenrieder 1996). CVA includes only cash items. It can be further explained as, the cash flow a company is able to generate over and above the cash flow it must generate to remain in business. That means CVA is the difference between company's operating cash flow (OCF) and Operating Cash Flow Demand (OCFD). 
Since CVA represents excess cash holding, the enterprise risk estimation will involve assessing the probability of depletion in CVA beyond a threshold possible. Risk estimation utilizes adaptation of Value-at-Risk (VaR). Utilizing a multi factor risk model with Monte-Carlo simulation is applied for estimating VaR. At a prescribed confidence level, $\mathrm{VaR}$ is the maximum loss possible for a given probability or in other words, variable exceeds the VaR only by same probability (Hendricks 1996). Here author utilizes $\mathrm{VaR}$ to capture the downside potential loss so as to prevent a insolvency crisis. Else, a low probability calamity may lead to liquidation of the entire enterprise. In this $\mathrm{VaR}$ adaptation, the percentage chance of losses going beyond a Financial Distress Threshold (FDT) is treated as the estimate of enterprise risk under usual conditions. Methodology utilizes essence of VaR with Extreme Value Theory (EVT) and Peaks-Over-Threshold (POT) method (Davison and Smith 1990) to estimate the percentage risk. Industry and regulatory bodies along with EU and Bank for International Settlements accepting $\mathrm{VaR}$ as the single standard quantification of risk, is one of the reason for its popularity (Marshall \& Siegel, 1996).

This study investigates the characteristics of enterprise risk displayed by BSE500 constituents. The study tries to understand the nature of variability demonstrated by risk and CVA (hereafter referred to as critical variables) under different categories of CGPI as well as at a micro-classification level such as age, size and industry (hereafter referred to as morphological factors) within CGPI categories to compare and contrast. It also tries to assess the nature and extent of relation existing between CGPI and risk undertaken. Finally, the paper examines the proportion of zero risk companies with respect to age and CGPI categories.

Study utilizes CVA as risk indicator and multivariate VaR methodology, in estimating enterprise risk for BSE 500 constituents. While descriptive analysis reveals the data properties, graphical analysis identifies the topology of the critical variables across classifications and categorizations. Coefficient of correlation and its signs indicates the nature and strength of relations existing among critical variables, statistical significance of critical variables across 18 
classifications and categories utilizing Tests of hypotheses undertaken.

There are not many studies that associate enterprise risk and CG to explore causality among them in Indian context. Relative studies across different classifications and categorizations that enable characterization of the critical variables are also a rarity in Indian scenario. This study instead of utilizing equations built based on western data, completely utilizes Indian data and contemporary methods like VaR for estimating risk.

VaR estimates the likelihood of loss to a financial variable at a certain confidence level during a defined time period. To estimate the potential loss, it is necessary to know the explanatory risk factors and their extent of correlations and their nature of influence. It is also necessary to define a loss threshold apart from statistical assumptions to define loss. This paper utilizes, VaR with MonteCarlo (MC) Simulation utilizing a linear process with adaptation of Peaks-Over Threshold methodology.

Risk is usually estimated with historical data. Therefore, it is more rearview looking than forward oriented. MC simulation provides us with futuristic scenarios based on assumptions, thereby giving a forward orientation. Success of the methodology depends on the comprehensiveness of the random scenarios to proxy the future. Even non-linear relations can be simulated with reasonable accuracy. (Frad \& Zouari, 2014)

Once parameters are estimated, specific distributions are chosen and linking functions are identified that will represent their comovements between outcome and the risk factors. Simulation process starts for the risk factors, which will eventually generate a distribution for the outcome variable from where $\mathrm{VaR}$ is estimated. This process is called Monte-Carlo (MC) simulation. VaR is the probability of making worst losses beyond a loss threshold and not an absolute value. (Cheung \& Robert, 2012)

Extreme Value Theory (EVT) relies on a threshold to determine the distribution of the tail composed of values beyond that threshold. EVT deals with extreme deviations from median of probability distributions. The Peaks-Over-Threshold (POT) approach focusses on the extreme values beyond the high threshold set. It assesses the 
probability of extreme events of a random variable. Thus, risk is determined based on left tail distribution rather than overall random variable distribution. (Vee et al., 2014)

Since variables are identified after testing their significance with standard statistical techniques, they are more appropriate to describe the Indian environment and their applicability will be better. Independent variables in the multivariate model assume significance due to the causal role it carries. Hence, it carries a management role due to its applicability in correcting, controlling and constantly improving the status of the dependent variable.

Results of this study contribute to several strands of literature associated with CG and risk. A better CG will allow agents to venture into high risk investments to assure higher value to stakeholders; and when there is a relaxation in CG, agents still venture on high risk investments with an eye on higher returns from equity when firm value is volatile, but market will treat such a firm as risky and in the long run will impact shareholder interest. There are strands of literature on the variables used in the estimation process and about the enterprise risk estimation methodology. Literature focuses on cash holding ability of any enterprise as a key determinant of the extent of risk. There are strands of literature on CVA which is a more up-to-date Value Based Measurement (VBM). As part of this paper CVA is seen as net pure profit that carries the potential for risk mitigation. There are strands of literature on estimation methodologies, but this paper focuses on $\mathrm{VaR}$ as method with a separate strand of papers discussing it.

The rest of the paper is organised as follows. Section 2 lists the objectives of the study. Section 3 explains the hypotheses. Section 4 is literature survey. Section 5 discusses the data and methodology. Section 6 is about limitations of the study. Section 7 is the empirical analysis and discussion of findings. Section 8 concludes the paper.

\section{Objectives of the study}

This study estimates the risk of BSE 500 constituents using CVA as the risk indicator with multifactor model for VaR estimation as the preliminary objective. Then, understanding the data properties of 20 
the critical variables and understanding the levels of risk across different categories of CGPI, across different morphological factors such as age and size of the corporates and types of industries will follow as secondary objective for understanding the topology of risk and CVA. Developing a Multivariate linear regression for CVA with statistically significant micro economic factors to develop distribution for CVA is integral to study. As part of the objectives, at a macro level, nature and strength of relations among risk, CVA and CGPI need analysis to conclude on the influence of CG performance on Enterprise Risk in the process. This is followed by a more intensive micro analysis of Risk and CVA at CG performance category level by further data dissection based on corporate age groups, industry membership and corporate size groups within CGPI categories and then a statistically intensive analysis will be performed to further understand the extent of influence CG performance has on Risk through ANOVA and Levene's test with Forsythe and Brown modification. Through an exploratory study, an analysis of proportion of zero risk companies across different categories becomes a subsidiary objective. Testing the assumptions set on critical variables about their differences around morphological factors as well as their significance of influence these factors exerts on critical variables becomes the ultimate objective.

\section{Hypotheses}

Ho: Average CVA across CGPI categories is equal

It is expected that there will be shareholder activism and management professionalism equally acting in high market (BSE 500C) segment. Therefore, there will always be a pressure to maintain and increase cash holding to fund expansions and manage troughs in business cycles. Hence cash in-flows will be competitive and differences within the high market segment can be insignificant as well.

Ho: Average Risk across CGPI categories is equal

An enterprise is exposed to risk from the macroeconomic and microeconomic dimensions. Macroeconomic factors act uniformly on the economy and therefore all companies are affected. While 
industry specific risk is uniform for companies in that industrial sector, firm-specific risks differ with companies. The effects of these risks need not be identical, as preparedness of companies differ with maturity in CG system. Since population consists of only high performing firms in the Indian market, the assumption is that their evolved CG practices will devise appropriate ERG systems that will mitigate the risk with sufficient actions.

Ho: Average proportion of zero risk companies across CGPI categories is equal

Companies that are better governed will demonstrate better resilience to risk due to ERG system in place. Therefore, even if their risk exposure is high, their probability of succumbing to risk will be low. Since population considered is from the high market of India, the assumption of more specialized CG practices and as a result a more evolved risk management system that will not expose firms to risk will exist is the assumption. Therefore, proportion of zero risk companies across the categories will not be significantly different.

Ho: Morphological factors has no influence on the CVA of companies

High performing companies are governed based on a well-defined and drafted management system. A documented system keeps companies neutral to morphological differences like age, size, industry representation etc. Also a documented system keeps the organisation neutral of individuals, enables monitoring of performance of the process without bias and creates venues for improvement and innovation activities on the process it follows. Hence, a high performing firm is assumed to have sophisticated documented systems to handle cash flow management in place that will neutralize morphological differences. Therefore, CVA of companies will not significantly differ.

Ho: Morphological factors has no influence on the risk profile of companies

Enterprise Risk Governance is part of CG system. When an evolved CG system is existing to support a high performing firm; as part of investor activism, a well evolved system to foresee, evaluate, 22 
analyse and act on the risk will be an integral part of it. A documented process based management system, alone can support the size, scale and complexity of operations BSE500 constituents undertake. Such a system will be independent of individual to create perpetual business operation. Therefore, system will support increasing size and age of organisation and derive improvement opportunities from history and will not let such factors to determine the nature of management to ensure higher stability and reliability an investor prefers to see in an organisation where they invest.

Ho: Risk is influenced by CVA and CGPI of the enterprise

Since CGPI levels determine the state of investor activism, which indirectly means existence of a evolved ERG system, that will control the risk exposure. When CVA increases, the pure cash profit that accumulates acts as a deterrent to risk. Therefore, while CGPI and CVA are positively correlated, they both are negatively correlated with risk is the assumption.

\section{Literature Survey}

Many of the studies in enterprise risk are in small and medium enterprise segment (Altman and Sabato 2007). Even with bigger enterprises, the ratings commercially available from specialized agencies are more relative and need not be absolute values of risk based on econometric models with foundations in firm and market performance parameters. Commercially available ratings do not indicate probability of default (Allen \& Powell 2011a).

From the time, Beaver (1966) used accounting data to predict bankruptcy, Ohlson (1980) using O score developed multivariate discriminant analysis, Bathory (1984) created a B score using a set of financial ratios to assess the financial health of an organisation. Altman (2010), using a Z score developed with 12 independent variables including macro-economic variables to develop a logit model to predict bankruptcy. Most of these models, while they have many advantages due to usage of accounting ratios such as implementation ease, comparability of predictions across firms etc.; they have their share of disadvantages too. Need for building industry specific models (He and Kamath 2006), predicted value 
remain static for a year as accounting information arrives annually (Vassalou \& Xing 2004), and relies on historical performance are few such issues (Queen and Roll, 1987). Accuracy issues (Grice and Dugan 2001) and model misclassification (Gutzeit \& Yozzo 2011) are also observed during recessions.

Another class of models used market information to predict bankruptcy. Among them Merton model is prominent. Here default is indicated when market value of firm's assets fall below total liabilities of the firm (Rikkers \& Thibeault, 2007). As these models incorporate market information they are more forward looking and dynamic in nature. Due to the complexity of the models and its inability to carry too many variables, the information factored to predict default is comparatively lesser (Allen and Powell 2011b).

Hillegesit et al. (2004), while comparing Merton model with classical models such as Altman (1968) and Ohlson (1980) models finds that the former is more information rich. A comparison of information revealed by both classes of models was undertaken by Lin (2007) with a sample of healthy firms to find that the information content in distance to default and expected default frequency is very low and being attributed to absence of trading that leads to overestimate of time to default due to lack of volatility. Lin, et al..(2012) finds credit default prediction models with accounting variables are better performers while using annual accounting data of traded small and medium enterprises.

Credit risk models which measure default probability or Value at Risk (VaR) attained a great deal of prominence with the proposal in Basel II to utilize the method to assess the capital adequacy of financial institutions. VaR based models provide a measurement of expected loss over a given time period at a given tolerance level. $\mathrm{VaR}$ can be implemented through different models such as covariance, parametric, and simulation models. Therefore, even when portfolio is same, the VaR estimate may differ with methodology underlying and its implementation to achieve a balance between accuracy and usability (Beder 1995, Hendricks 1996). Variation in estimate may be due to the assumptions involved, the type and complexity of instruments in the portfolio, and finally the market in which it is tested (Marshall \& Siegel, 24 
1996). VaR estimates can vary when wrong assumptions are made on the distribution of the variable or if the variable demonstrates a time varying volatility (Sinha \& Chamu 2000). Despite the adverse remarks, VaR summarizes an array of risks such as market risk, liquidity risk, operational risk etc. through a single number that denotes the probability of risk or even risk itself (Manganelli \& Engel, 2001).

Decisions of investments are influenced by the biases induced by the accounting process. Therefore, the inputs considered for the decision must be rational in nature. It must consider the discounted cash flow to finalize on the choice. Discounted cash flow gives the investor a perspective of value that they realize out of the investment that they have made. To measure the value, it is essential to segregate the strategic investments and the nonstrategic investments that enable realization of value out of strategic investments. Latter is considered as cost and net financial outcome is the value generated for the investor. (Ottosson \& Weissenrieder 1996) Surplus value creates cash reserves for expansion and risk management.

While CVA indicates the cash flow and its risk mitigating ability, its value add is questioned by Fernandez (2013) as computation of CVA relies on accounting statements that is reflecting history rather than the future. But, at the same time, paper agrees to the fact that due to the refinement of earnings with cost of capital makes it a business performance metric.

Weissenrieder (1997), assumes cash flow is in equal amounts discounted using capital cost. But Jacobs (2003) comments that cash flow in equal amounts is just one of the many possible patterns cash flow can follow. The criticism continues, with Jacobs identifying OCFD as defined demand of equal amounts in every period, while OCF is real money at the end of a time period, therefore CVA is derived out of non-comparable measures. Moreover, OCFD is the perception of the investor or manager of the enterprise and it can even change from time to time, hence it cannot be a reference.

Recent studies in China on SME firms using Bathory model reveals a negative correlation of financial risk with solvency, profitability 
and capital structure. Study also identifies a state of no correlation with debt structure (Gang \& Dan, 2012). Similar study in India reveals a negative correlation with solvency, profitability and capital structure, but positively related with current ratio, quick ratio, net profits and net assets ratio (Bhunia, 2012).

Despite CG systems existing to check the risk management practices, so long as executives find stock options as an item in their remuneration structure, their motivation to venture into riskier investments will trigger a conflict of interest between shareholders and executives. With riskier business projects, earnings fluctuations will follow which leads to firm value volatility that makes firm riskier. Firm value volatility has a possibility to deteriorate firm's market performance that acts detrimental to the interest of the shareholders. (Blanchard \& Dionne 2003, Litov et al. 2007)

Even the best of the systems can fail, since risk management is highly quantitative in nature, and therefore a limitation on the competency of the risk management team members may act as a constraint in evaluating thread bare all the possibilities of loss making. Thus, recommendations of such a team made to board will have lacunae which will make board decisions vulnerable to failure, thereby questioning the state of CG in the firm. (Healy \& Palepu 2003, Smith \& Stulz, 1985)

Dionne and Triki (2005) identified that financial distress cost, information asymmetry and risk appetite of the management determines the effectiveness of risk management. The study also finds that hedge ratio is directly proportional to the distress cost. Higher the distress cost use of innovative instruments for hedging raises the risk. In countries where shareholder rights are lower, there are evidences to suggest manipulation of cash flow (Leuz \& Nanda 2003) that makes firms riskier. This is a situation of weak CG as the intent of CG to improve the shareholder value gets defeated and the firm gets riskier.

\section{Data and Methodological Framework}

Secondary data from CG reports of BSE 500 constituents of the year 2012 forms the basis of this content survey study (Beattie \&Thomas, 26 
2006). For these 500 companies, CG reports available in annual reports are collected. For a few companies, despite the best of efforts to find these reports in Prowess, BSE website, internet searches, were not available. Data collection plan (Table 5.1) driven survey of published reports provides the cross sectional data of 2012 for computing Corporate Governance Performance Index (CGPI) and further analyses.

\section{CGPI Computation:}

Every question in the data collection plan is assessed on Osgood's Semantic Differential Scale. An interval scale of zero to five with five as the highest rating is aligned to the attributes. CGPI computation happens in three layers. In the first layer, scores for attributes are assigned, in the second layer, indices for each theme is computed, and in the third layer CGPI is computed. A theme index is computed with cumulative sum of scores for the attributes associated with a theme by the maximum possible score out of that theme, as a percentage. Simple aggregation of scores implies unweighted index. In the third layer, average of the theme indices is considered as the CGPI. (Sarkar et al., 2012)

Based on the data distribution of CGPI, categories are identifiable. Boundaries of categories are statistically defined based on the distance in terms of standard deviations from mean of the dataset (Sarkar et al., 2012). Categories are from one to five with one being the excellent and other descriptive phrases for two to five in the sequence will be Matured, Optimum, Fair, and Poor.

Firm Morphology:

Data for corporate age (hereafter, age), market capitalization and industry membership for BSE 500C Index constituents are extracted from Capitaline database for the year 2012. Age is computed from the year of incorporation till 2012 in terms of years. Market capitalization data is downloaded as on 31/12/2012. Industry membership for the companies at possible granularity available in the database is collected and mapped to five major industries as in Table 3. 
Industry wise classification of the BSE500C constituents is as follows: Manufacturing, Services, Mining \& Refining (M\&R), Infrastructure, and Trading. Age classification is based on the quartiles of the age dataset. Quartile 1 is level1 (0-22), quartile 2 is level 2 (23-31), quartile 3 is level 3 (32-58), and quartile 4 is level 4 (58 and above). Size (Market cap) classification also follows the quartile approach with first quartile is level1 (0 to $1430 \mathrm{Cr}$ ), second quartile is level 2 (1431Cr to3198Cr), third quartile is level 3 (3199Cr to $9082 \mathrm{Cr}$ ), and fourth quartile is level 4 (9082Cr and above).

CVA Computation:

CVA is computed for the entire population of BSE500C companies. This derived metric utilizes accounting variables as base measures. All the necessary accounting information is downloaded from Prowess Database. CVA is computed manually with the aid of accounting information available. CVA computation utilizes the formula available in Bayrakdaroglu (2012).

\section{$C V A=$ GrossCashFlow - EconomicDepreciation - CapitalLoad}

Where,

GrossCashFlow $=$ EBDIT - Tax

EconomicDepreciation $=\left[\frac{W A C C}{(1+W A C C)^{n}-1}\right]($ FixedAsset $)$

CapitalLoad $=\%$ WACC $*$ InvestedCapital

InvestedCapital $=$ TotalAssets - CurrentLiabilities

Weighted Average Cost of Capital (WACC) and Earnings before Depreciation Interest and Tax (EBDIT) utilizes standard formula and computation. 


\section{Econometric modelling and VaR Computation:}

Out of the financial ratios covering 15 categories such as liquidity, efficiency, profitability, turnover, leverage, cash flow, sales, income, labor, discretionary cost, foreign risk, investment, market value etc. that is computed, it is necessary to find the relative importance of different attributes with respect to the influence it generates on CVA. Towards achieving this goal, a subset of ratios that represents the total variability in the data is identified with factor analysis. Factor analysis is performed on the financial ratio data using Principal Component Analysis (PCA) with Varimax rotation. Attributes carrying factor loading greater than 0.8 are considered for Ordinary Least Squares (OLS) Regression analysis with CVA. During this process, based on statistical significance of regressors identified with $p$-value of coefficients and existence of multicollinearity identified with Variance Inflation Factor (VIF), further refinement in the set of regressors happen. These ratios are connected to CVA through OLS regression to create a multi factor risk model to estimate VaR in Indian context.

$$
C V A=\beta_{0}+\sum_{i=1}^{n} \beta_{i} \text { FinancialRatio }_{i}+\varepsilon_{i}
$$

Using MC Simulation based on mean and standard deviation of the financial ratio regressors in the multifactor model, a probability distribution of CVA is generated. Adapting EVA with POT methodology, certainty is computed based on the probability of achieving a lesser CVA from the median CVA already achieved (Fig 5.1). Thus probability of achieving lower than the median threshold set at $95 \%$ confidence level is identified as the enterprise risk associated with a company using a seven year period. Similarly, the procedure was replicated for all the companies in the population that was part of model building.

In this study, median is chosen as the threshold not only to align with the EVT principles but also with Enterprise Risk Management (ERM) practices. As part of ERM, risk signals need to be sensed well in advance to plan the strategy of management. As part of the strategy, management must get enough time to react with mitigation, and then monitor till it reaches a more critical zone to 
initiate a contingency plan. Moreover, it was observed that most of the BSE500C companies carry a negative CVA as per the computation followed. Since all the companies are top performers in the market, having negative CVA need not be a hazard, but knowing the risk a little early and staying prepared for the eventuality is the norm applied.

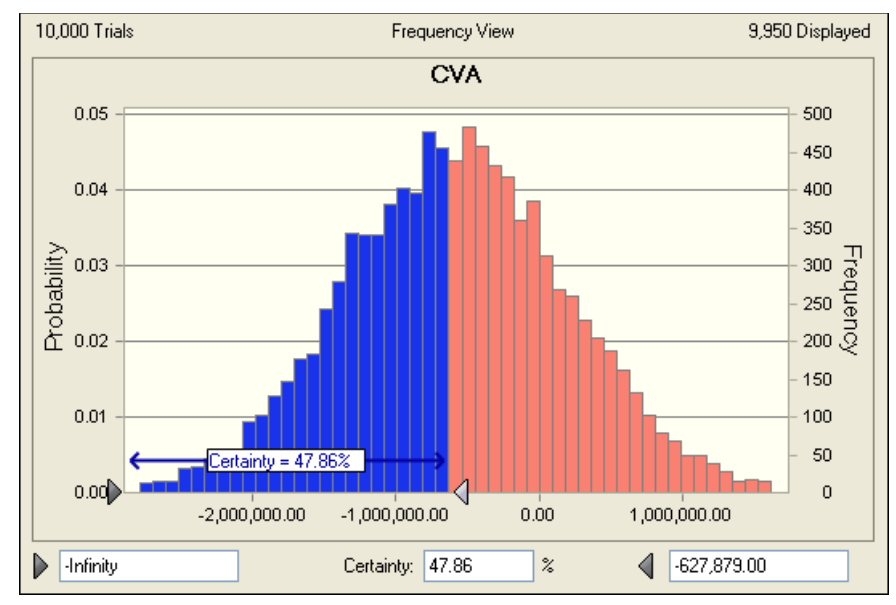

Fig 5.1Multi Factor Model for Estimating Risk with VaR

\section{Limitations of the study}

This study utilizes only Indian data of a short period of approximately ten years. Since the data is from BSE 500 top performing companies and it is not a complete and accurate representation of the corporate sector in India, applicability of the conclusion on entire Indian market is challengeable. As it uses accounting variables and adjustments applied can be different in different companies, the homogeneity of the data cannot be assured, and there is a possibility of bias. Accounting data is also vulnerable to manipulation; therefore, derived measures are liable for misinterpretation. Conditions such as normality, stationarity, random walk and time consistency remain assumed and it will not impact the ultimate results of the study. 


\section{Analysis and discussion of findings}

\section{Multi factor model for VaR estimation}

A multi factor model for $\mathrm{VaR}$ estimation is created as an adaptation of the concept of component $\mathrm{VaR}$ but model here is utilized for the purpose of establishing correlation and causation. Finally, MC Simulation is conducted to generate a predicted value distribution for CVA so that it is future oriented. The statistically valid multifactor model is as follows:

\section{$C V A=2824-17301$ EquityMultiplierRatio-7.8TimesInterestEarned-834OperatingM arg in}

Equity Multiplier (EM) ratio, Times Interest Earned (TIE) and Operating Margin $(\mathrm{OM})$ work as a single system of variables with internal pathway that will act as a negatively correlated single variable with CVA. Due to the high coefficient of the EM ratio, even a marginal dip in the ratio will have a significant negative impact. Also, the negative coefficients of other regressors will contribute to the negative movement of the overall system of regressors that will promote CVA growth as per the equation. A higher EM ratio means that more assets are funded by debt than by equity. When a firm's assets are primarily funded by debt, the firm is considered to be highly leveraged and more risky for investors and creditors. This also means that current investors actually own less of the company assets than current creditors. Companies that rely too heavily on debt financing will have high debt service costs and will have to raise more cash flows in order to pay for their operations and obligations. Debt service cost will impact the operating income (Earnings Before Interest and Tax, in short EBIT). Therefore, a reduced EM ratio will assure increase in EBIT which will positively trigger a rising TIE ratio and OM increase will be a natural outcome that will eventually trigger a rising CVA. Thus, this performance management model not only can estimate $\mathrm{VaR}$ but also can be used to manage $\mathrm{VaR}$, as Risk and CVA are positively correlated as per the study findings that follow.

\section{Descriptive Statistics}

To understand the statistical properties of CVA and Risk, descriptive statistics is analysed (Table 7.2). Categories are created 
based on CGPI scores. Category 1 companies are high performing firms with respect to CGPI and other categories from 2 to 5 are in ordinal ranking created with relatively lower levels of CGPI performance scores.

Category 1 on the basis of CGPI based categorization scale has relatively a higher risk mean than the rest, while category 2 has the lowest risk mean. Risk means of all categories are statistically significant at $95 \%$ confidence level by $t$ test. Standard errors of all categories except category 1 indicate means are statistically significant and hence they are significantly different from population risk mean. Median values different from mean values suggest skewness in the distribution. Category1 companies demonstrated higher relative variability in risk when compared to other categories due to its higher coefficient of variation. A negative kurtosis for categories 2 and 3 indicate a platykurtic distribution for all categories and a positive kurtosis for other categories suggest a leptokurtic distribution. All categories promote a negative skewness in its risk distribution. Range of all categories indicates uniform existence of extreme risk performance from risk free to cent percent risky types of firms.

In Table 7.2 Panel B, Category 5 mean of CVA is higher than the rest of the categories and all means are statistically significant at $95 \%$ confidence level by $\mathrm{t}$ test and as their standard errors are high, these means are significantly deviated from population mean. Widely different median value suggests distribution is significantly skewed. Uniform mode value of zero in all categories indicates a significant number of companies are there in every category that is on the border line of having a positive CVA. High coefficient of variation of CVA across all categories indicates higher variability. High positive kurtosis indicates a leptokurtic distribution for CVA in all categories. All categories are negatively skewed for CVA distribution. Large range values indicate existence of extreme CVA values in the categories.

At the industry level comparison within categories for risk (Fig. 7.1), category 1 has manufacturing and services at approximately same high risk. In category 2 and 3, services carry higher risk than rest. In category 4 , trading firms has a higher risk. In category5, manufacturing, mining and refining, and services while are neck to 32 
neck, there is marginal ranking among them in the same order with manufacturing carrying a higher risk. To generalize, except in category 4 and 5, in all other categories service sector carries high or even highest risk, then comes manufacturing as high risk sector. In the extreme ends of the CGPI spectrum it is manufacturing sector that carries the highest risk.

Except in category 4, every other category has M\&R sector representing the lowest CVA. Similarly, trading and services cover $80 \%$ of categories with High CVA. Services appear with high CVA on both extreme ends of the category scale. Similarly M\&R has the lowest CVA on both extreme ends of the category scale (Fig.7.2). In mid portion of the scale where category 3 and 4 appear, trading and infrastructure industries have high CVA. Overall, trading industry has the highest CVA arising from categories 2 and 3 , in the same way; M\&R has lowest CVA arising from categories 1 and 2 (Fig. 7.4).

Except in category 4, every other category has manufacturing or services representing the highest risk. Manufacturing appears with high risk only on both extreme ends of the category scale (Fig.7.1). In mid portion of the scale where category 2 and 3 appear, services industry has high risk. Overall, manufacturing, services and trading industries contribute to high risk through categories 1, 2 and 4 respectively. In the same way, M\&R has lowest risk arising from category 2. In short, $80 \%$ of categories have either manufacturing or services as contributor of highest risk. To summarize, those industries are identified as high risk industries (Fig. 7.3).

A comparative analysis of average risk across categories after excluding risk free companies (Fig. 7.5) suggest that category 1 high CGPI firms have high risk, then category 2 firms have the lowest risk. From there to category 5 it is an ascending trend. This suggests that high CGPI firms, to maintain their high market performance are susceptible to shareholder activism, leading the management to riskier projects. Category 2 firms are comparatively less competitive as they are being treated in the top bracket. Maintenance of the position is the priority and hence they are not under undue pressure to increase market performance taking unreasonably risky projects while firms in categories 3 to 5 are 
under pressure from their stakeholders to increase their market performance and improve their CGPI ranking, thus embarking on risky ventures. Hence, extreme ends of the categorization scale are extremely risky.

The above described trend gets further strengthened, while observing the CVA trends across categories (Fig. 7.6). Categories 1 and 5 have lowest CVA. This may be because of the amount of debt that is their capital structure. This will increase the interest expense and interest payable, which will impact the operating income and thus OCF will deplete leading to lower CVA. Category 3, though under pressure to improve performance still has highest CVA, may be because of the lower amount of debt that brings down interest payable which improves invested capital and reduces capital load which is the last term in CVA computation. This also may be due to the better management of depreciating assets that impacts the economic depreciation which is the middle term in the CVA computation.

Relations study performed on CGPI, CVA and Risk reveals in Table 7.2 the following facts. Except category 1, all categories associate CGPI and CVA on negative correlation, which means when either of the variable increases, the other decreases. Though the strength of correlation is below $50 \%$, still its direction is significant.

From category 3 to 5, when CGPI is decreasing CVA is increasing, that is leading to increase in risk eventually concluding that a decreasing CGPI leads to increased risk. The possible mechanics behind this phenomenon could be, a reduced shareholder activism is resulting in agents resorting to riskier projects that creates volatility in cash flows that eventually raises the risk.

For category 2, when CGPI is decreasing, CVA is increasing, but then risk is also increasing, eventually concluding that a reducing CGPI leading to reducing risk. Here, a potential explanation could be, being a matured CGPI category, the firms in this segment will favor maintenance of the CG performance status quo and in the interest of improving valuation, acquires higher operational efficiency, and selection of rational projects that may lead to higher possible operating income. Thus CGPI decreasing leads to moderate CVA increase and minimal risk rise as well. Therefore, in 34 
the absence of debt and risky projects, overall, the risk movement with respect to CGPI will be a positive correlation, which means when CGPI decreases, then risk also decreases.

For category 1, when CGPI, CVA and risk are positively correlated with one another, possibly due to the excellent CG performance, there is an inherent pressure to maintain the status quo and improve on the same. In that process, shareholder activism presses injection of additional debt financing with the intention to increase cash flow as well to ensure control on the discretionary spending of the agents plus adoption of riskier projects to enhance the value. Thus, a potential credit risk as well as volatile cash flows out of risky projects increases the enterprise risk.

Therefore, factors impacting operating income get influenced by the determinants of corporate governance performance. The negative correlation in category 5 signifies the higher risk due to a relaxed CG performance and as firm rises to category 1, CGPI improves and risk also increases as part of the corporate strategy to rise in value by accepting calculated risks in generating the operating income. Thus, there exists a strong correlation between CGPI and risk, suggesting an increasing risk on the either extremes of the category scale. This signifies the importance of the methodology adopted to increase the CVA may increase risk as well. When CGPI determines CVA and, when CVA determines risk, it is an associative property that we investigate in the relation between CGPI and risk.

At $95 \%$ confidence level, Analysis of Variance (ANOVA) studies reveal that by observing $\mathrm{p}>0.05$, test fails to reject the null hypothesis, which means that, the means of the risks did not significantly differ with different age groups $(p=0.824252)$ as in Table 7.4. Similarly, mean of the risks did not significantly differ with different enterprise size groups $(\mathrm{p}=0.774482)$ as in Table 7.6. But when $\mathrm{p}<0.05$, test rejects the null hypothesis to mean that, the means of the risks did significantly differ with different industrial segments $(\mathrm{p}=0.016353)$ as in Table 7.5.

Table 7.7 carries results of ANOVA studies on mean of CVA in different age groups. At 95\% confidence level, $p>0.05$, leads to the interpretation that differences among the means of the CVA across 
different age groups are statistically insignificant $(p=0.0688)$. Similarly, when means of the CVAs are compared across different enterprise size groups, test finds that there are no significant differences among the means of the CVA across different age groups $(p=0.06973)$ as in Table 7.9. But, when means of CVA are compared across industry segments, a $p<0.05$ leads to the interpretation that there is a significant difference among the CVA across industry segments ( $p=0.000978)$ as in Table 7.8.

While performing Levene's Test with Brown and Forsythe modification to assess the risk variances, it was observed that at $95 \%$ confidence level, $p>0.05$, leading to the inference that the differences in the variances in risk across age groups $(p=0.94395)$, industry segments $(p=0.798424)$ and size groups $(p=0.924359)$ are statistically insignificant, which means, it failed to reject the null hypothesis that the risk variances are equal.

In an identical process to assess the CVA variances, it was observed that at $95 \%$ confidence level, $p>0.05$, leading to the inference that the differences in the variances in risk across age groups $(\mathrm{p}=0.6108)$, industry segments $(\mathrm{p}=0.110703)$ and size groups $(p=0.672572)$ are statistically insignificant, which means, failed to reject the null hypothesis that the variances are equal.

While performing an ANOVA on the proportion of risk free companies among different industries $(\mathrm{p}=0.07951)$, age groups $(p=0.085774)$, and size groups $(p=0.085774)$, at $95 \%$ confidence level, study failed to reject null hypothesis, which means the differences in the means of proportion of risk free companies across the different industries, age groups and size groups are statistically not significant.

It is also noticed that there exists a significant difference in the proportion of risk free companies across CGPI categories, when data is segmented based on size groups as $p<0.05$. This leads to rejection of the null hypothesis which states that between CGPI categories, differences in proportion of risk free companies are statistically insignificant $(\mathrm{p}=0.049028)$.

A Pareto Analysis reveals that Manufacturing and Services industry combined, contribute $80 \%$ of the risk free firms (Fig. 7.7). In terms of market capitalization, group 4 and group 3 covers $80 \%$ 36 
of risk free companies (Fig. 7.8). The results were identical for classification based on corporate age. Cat 3 and Cat2 of the CGPI categories covered $80 \%$ of the risk free firms (Fig.7.9). This result again, reiterates the fact that the firms in the either extremes of the CGPI ordinal scale are riskier due to varying degree of stakeholder activism and nature of agent intervention.

\section{Conclusion}

This study searches for a CG performance measure that is rooted in financial performance metric that also reflects the value of the firm. The risk exposure of such a variable will emerge as a better indicator of risk. Cash holding is a financial metric as well as it carries the ability to deter any credit risk that will erode the value of the firm. It is also a key proxy of CG significance because of its role in agency theory. From the stable of VBM, CVA finds its way into the study as it meets all the criteria for qualification. Since discounted cash flow is a means of estimating the value of the investment, a risk model on such a variable is more appropriate. Thus, CVA emerges as a means for estimating value and represents surplus cash reserves that provides means to expand and cover risk, thus creating value (Ottosson and Weissenrieder 1996).

From the time of Beaver (1966) till Altman (2010), an array of risk prediction models arrived. Since these models employ annually reported accounting figures, they are lagging. Then come $\mathrm{VaR}$ based models that provide a measurement of expected loss in a given period of time, and can summarize an array of risks (Manganelli and Engel 2001). Now, enterprise risk is the downside risk of CVA beyond a threshold.

A multifactor estimation model for $\mathrm{VaR}$ is established for CVA which will provide not only with a risk estimate through MC Simulation, but also a strategy to manage the Risk through the causal factors that appear as regressors. The study estimates the enterprise risk of BSE500 constituents. Since CVA and risk are critical variables in the study, their properties are analysed independently and jointly with CGPI. Nature and strength of influence of CG performance on risk is evaluated through correlation coefficient. At CGPI category level, risk data was 
dissected based on morphological factors of the companies, then using test of hypothesis for mean and variance, the significance in differences among means and among variances were investigated. In the last level of analytics, proportion of risk free companies across categories and morphological factors were analysed with test of hypothesis and Pareto Analysis.

While CVA is statistically significant across CGPI categories and industrial segments, it is insignificant across age groups and size groups. The average CVA of category 1 and category 5 are the lowest when compared with rest of the categories. There exists companies which are on the borderline to have positive CVA in all categories. M\&R sector consistently demonstrates low CVA while services and trading demonstrates a high CVA in most categories. Services and M\&R sector demonstrates the highest and lowest CVA respectively in the best performing and worst performing CGPI categories.

On the CGPI scale, category 5, lower performing companies demonstrate relatively higher mean risk. But a median analysis performed without risk free companies reveals that category 1 has the highest median risk while category 5 is marginally lower than category1.This brings out the significant influence of zero risk companies in both these categories influencing the analytics and inference. Statistically, the means of the risk are significant among the different CGPI categories and industrial segments, but insignificant between different age groups and size groups. While standard errors signify that the means of the risk are significant, coefficient of variation suggest variability in risk is more among category 1 firms. All categories carry risk free firms as well, and statistical analysis finds significant differences among categories with respect to proportion of risk free companies. More or less uniformly service sector registers high risk among the industry sectors, followed by manufacturing. In contrast, manufacturing and service contributes $80 \%$ of the total risk free companies.

Category 1 companies demonstrate a positive correlation between CGPI score and Risk, which signifies a possible shareholder activism to increase the firm value by forcing agents to take risky means under pressure to demonstrate sustained high CG performance. A negative correlation that exists in category 5 38 
companies signifies agents taking decisions on project financing and project selection completely based on their will under the condition of fading stakeholder influence leading to higher risk. Correlation inference finds support from the analysis on proportion of risk free companies across categories revealing category 3 and 2 covering $80 \%$ of the risk free companies.

The study leaves multiple areas for further examinations like role of debt in the capital structure of firms in the extreme ends of the CGPI scale; investigate role of certain industrial segments, age groups and size groups in influencing CVA and risk are few of them. This study has potential to exercise significant influence on policy decisions on Corporate Governance. It reiterates the strategic role of $\mathrm{CG}$ by underlining the need for bringing in corporate strategy and its impact within the ambit of CG. CG of a firm is ultimately responsible for its growth and sustenance. To achieve this, operational efficiency, corporate finance and economic intelligence functions must unite to ensure financial performance and related risk reduction. This convergence must be mediated by a corporate policy on CG. Thus CG must be all inclusive function that covers social and financial performance that will mitigate the risk and balance growth.

\section{References}

Acemoglu, D., Johnson., S., Robinson, J., \& Thaicharoen, Y. (2003). Institutional causes, macro-economic symptoms: Volatility, crises, and growth. Journal of Monetary Economics, 50(1), 49- 123.

Agrawal, A. \& Chadha, S. (2004). Corporate governance and accounting scandals. Retrieved from Social Science Research Network: http://ssrn.com/abstract=595138.

Agrawal, A., \& Chadha, C. (2004). Corporate governance and accounting scandals. Retrieved July 10, 2014, from http://ssrn.com/abstract=595138, pp.1-47.

Allen, D. E \& Powell, R.J. (2011). Customers and markets: Both are essential to credit risk management in Australia. Australasian Accounting, Business and Finance Journal, 5(1), 57-75.

Allen, D. E., Singh, A. K., \& Powell, R. J. (2011). Value at risk estimation with extreme value theory. Paper presented at the $19^{\text {th }}$ international congress on modeling and simulation 
(ModSim2011). Retrieved from http://mssanz.org.au/ modsim2011, 1478-1484.

Alman, E.I. \& Sabato, G. (2007). Modeling credit risk for SMEs: Evidence from the U.S. market. Abacus, 43(3), 332-357.

Altman, E., (1968). Financial ratios, discriminant analysis and the prediction of corporate bankruptcy. The Journal of Finance, 23, 589-609.

Altman, E., (2010). The $\mathrm{Z}$ metrics methodology for estimating company credit ratings and default risk probabilities. Risk Metrics Group, Retrieved from https://www.fdic.gov/ regulations/ reform/Altman2.pdf, 1-45.

Bathory, A., (1984) Predicting corporate collapse - Credit analysis in the determination and forecasting of insolvent companies. London: Financial Times Business Information Ltd.

Bayrakdaroglu, A., (2012). Is there a relationship between corporate governance and value-based financial performance measures? A study of Turkey as an emerging market. Asia-Pacific Journal of Financial Studies, 4, 224-239.

Beaver, W. (1966). Financial ratios as predictors of failures, Journal of Accounting. Research, 6, 71-102.

Beder, T. S. (1995). VAR: Seductive but dangerous. Financial Analysts Journal, 12-24.

Bhunia, A. (2012). Financial risk measurement of small and medium-sized companies listed in Bombay Stock Exchange. Research Journal of Business Management and Accounting, 1 (3), 4045.

Blanchard, D., \& Dionne, G. (2003). Risk management and corporate Governance. Retrieved July 20 2014 from $h t t p: / / s s r n . c o m / a b s t r a c t$ $=441482,1-8$.

Cheung, Y.H \& Robert J.P., (2012). Anybody can do value at risk: A teaching study using parametric computation and monte carlo simulation. Australasian Accounting, Business and Finance Journal, Vol. 6(5), 101-118.

Damodaran, A., et al., (2012). Risk Taking: A Corporate Governance Perspective, International Finance Corporation (World Bank Group), http://www.ifc.org, pp.1-64 (Accessed on: 15/07/2014).

Davison A.C., \& Smith, R.L. (1990). Models for exceedances over high threshold. Journal of the Royal Statistical Society, 2(3), 393442. 
Dionne, G., \& Thouraya, T. (2005). Risk management and corporate governance: the importance of independence and financial knowledge for the board and the audit committee, Retrieved July 15th 2014 from http:/ / ssrn.com/abstract=730743,1-53.

Dyck, A., \& Zingales, L. (2004). Private benefits of control: An international comparison. The Journal of Finance, LIX (2), 537600.

Fernandez, P. (2011). EVA and cash value added do not measure shareholder value creation. Retrieved July 20 2014 from http://ssrn.com/abstract=1961087, 1-15.

Frad, H., \& Zouari, E. (2014). Estimation of value-at-risk measures in the Islamic stock market: approach based on extreme value theory (evt). Journal of World Economic Research, 3(2), 15-20.

Gang, F., \& Dan, L. (2012). Research on the influence factors of financial risk for small and medium sized enterprise- an empirical analysis from 216 companies of small plates, ShenZhen Stock Exchange-China. Interdisciplinary Journal of Contemporary Research in Business, 3 (3), 1-8.

Grice, J., \& Dugan, M. (2001). The limitations of bankruptcy prediction models: Some cautions for the researcher. Review of Quantitative Finance and Accounting, 17(2), 151-166.

Gutzeit, G., \& Yozzo, J. (2011). Z-Score performance amid great recession. American Bankruptcy Institute Journal, (2), 44-46.

Harford, J. (1999). Corporate cash reserves and acquisitions. The Journal of Finance, 54(6), 1969-1997.

He, Y., \& Kamath, R. (2006). Business failure prediction in retail industry: an empirical evaluation of generic bankruptcy prediction models. Academy of Accounting and Financial Studies Journal, 10(2), 97-110.

Healy, P. M., \& Palepu, K. G. (2003). The fall of Enron. The Journal of Economic Perspectives, 17, 3-26.

Hendricks, D. (1996). Evaluation of value-at-risk models using historical data. Economic Policy Review, 2(1), 1-32. Retrieved July 20 2014 from http://ssrn.com/abstract $=1028807$.

Hillegeist, S. A., Keating, E. K., Cram, D. P., \& Lundestedt, K. G. (2004) Assessing the probability of bankruptcy, Review of Accounting Studies,.9, 5-34.

Isshaq, Z., \& Bokpin, G.A., \& Onumah, J.M. (2009). Corporate governance, ownership structure, cash holdings, and firm value 
on the Ghana Stock Exchange, The Journal of Risk Finance, 10(5), $488-499$.

Jacobs, J. F. (2003). Like EVA, the CVA concept cannot stand the test either. Retrieved form July 25th 2014, from http://ssrn.com/ abstract $=378501$.

Jensen, M., \& Meckling, W. (1976). Theory of the firm: managerial behavior, agency costs, and ownership structure. Journal of Financial Economics, 3, 305-360.

Jensen, M.C. (1986). Agency costs of free cash flow, corporate finance and takeovers. American Economic Review, 76, 323-329.

Leuz, C., Nanda, D., \& Wysocki, P. D. (2003), Earnings management and investor protection: an international comparison. Journal of Financial Economics, 69, 506-527.

Lin, S. M., Ansell, J., \& Andreeva, G. (2011). Predicting default of a small business using different definitions of finance distress. Journal of the Operational Research Society, 4(63), 539-548. doi:10.1057/jors.2011.65.

Lin, S., (2007). SME credit risk modeling for internal rating based approach in banking implementation of basel2 requirement ( $\mathrm{PhD}$ Thesis at University of Edinburgh). Retrieved from, https://www.era.lib.ed.ac.uk/bitstream/1842/4914/1/Lin\%20 2007.pdf,1-270.

Litov, L. P., John, K., \& Yeung, B.Y. (2007). Corporate Governance and Corporate Risk Taking: Theory and Evidence. Retrieved on 20th July 2014, from http:// ssrn.com/abstract=979413, pp.1-67.

Manganelli, S., \& Engle, R. F. (2001). Value at risk models in finance. Retrieved July 15 2014 from http://ssrn.com/ abstract $=356220,1-41$.

Marshall, C., \& Siegel, M. (1996). Value-at-Risk: Implementing a risk measurement standard. Retrieved July 15th 2014 from http:/ / ssrn.com/abstract=1212, 96-47.

Myers, S. C., \& Rajan, R.G., (1998). The paradox of liquidity. Quarterly Journal of Economics,108, 733-771.

Nocco, B.W., \& Stulz, R.M. (2006). Enterprise risk management: Theory and practice. Retrieved July 15the 2014 from http:// ssrn.com/abstract=921402.1-33.

Ohlson, J. A. (1980). Financial ratios and the probabilistic prediction of bankruptcy. Journal of Accounting Research, 1.18 (1), 1-24. 
Ottosson, E., \& Weissenrieder, R. (1996). Cash value added - A aew method for measuring financial performance. Retrieved from http://ssrn.com/abstract $=58436,1-10$.

Queen, M., \& Roll, R. (1987). Firm mortality: Using market indicators to predict survival. Financial Analysts Journal, 43, 9-26.

Rikkers, F., \& Thibeault, A. E. (2007). The optimal rating philosophy for the rating of SMEs, Retrieved July 20 2014 from http:/ / ssrn.com/abstract=966322, 1-17.

Shleifer, A., \& Vishny, R.W. (1997). A survey of corporate governance. The Journal of Finance, 52, 737-783.

Smith, C. W., \& Stulz, R. M. (1985). The determinants of firms' hedging policies. Journal of Financial and Quantitative Analysis, 20(4), 391-405.

Vassalou, M., \& Xing, Y. (2004). Default risk in equity returns. The Journal of Finance, 59, 831-868.

Vee, D. N. C., Gonpot, P. N., \& Sookia, N. (2014). An application of extreme value theory as a risk measurement approach in frontier markets. International Journal of Mathematical, Computational, Physical and Quantum Engineering, 8(6), 878-888.

Weissenrieder, F. (1997). Value based management: Economic value added or cash value added?. Retrieved July 20th 2014 from http:/ / ssrn.com/abstract=156288, 1-42.

\section{Annexures}

TABLE 5.1

\section{CLASSIFICATION OF DATA COLLECTION PLAN}

Data collection plan is classified into themes and within themes there are attributes. There are seven themes and forty attributes identified from CG reports in SEBI EDIFAR filing and for every theme more granular information is captured through a set of questions called as attributes.

\begin{tabular}{|c|l|c|}
\hline \hline \multicolumn{1}{|c|}{ Broad Themes } & $\begin{array}{c}\text { No. of } \\
\text { Attributes }\end{array}$ \\
\hline \hline 1 & $\begin{array}{l}\text { Board of Directors (functions, training, } \\
\text { shareholdings etc.) }\end{array}$ & 7 \\
\hline \hline 2 & $\begin{array}{l}\text { Board Meetings (duration, procedure, attendance } \\
\text { etc.) }\end{array}$ & 4 \\
\hline \hline 3 & CG committees (CG, nomination, strategy etc.) & 8 \\
\hline 4 & CG initiatives (Whistle Blower Policy, CG ratings, & 5 \\
\hline
\end{tabular}




\begin{tabular}{|c|l|c|}
\hline & succession planning etc.) & \\
\hline 5 & $\begin{array}{l}\text { Review of committees (nomination, audit, CSR } \\
\text { etc.) }\end{array}$ & 8 \\
\hline \hline 6 & $\begin{array}{l}\text { Shareholders (dividend history, changes in equity } \\
\text { capital etc.) }\end{array}$ & 7 \\
\hline \hline 7 & Awards or accolades & 1 \\
\hline \hline & Total & 40 \\
\hline
\end{tabular}

Adopted from Bhasin (2012)

\begin{tabular}{|c|c|c|c|c|}
\hline \multicolumn{5}{|c|}{ TABLE 5.2} \\
\hline \multicolumn{5}{|c|}{ CATEGORIZATION OF FIRMS BASED ON CGPI } \\
\hline \multicolumn{5}{|c|}{$\begin{array}{l}\text { Content survey of } 471 \text { firms out of BSE } 500 \text { index listed companies } \\
\text { creates the data sheet with question level scores. Scores were } \\
\text { aggregated component wise and component index is computed as a } \\
\text { percentage score. CGPI is the average of the component indices. By } \\
\text { looking at the CGPI distribution }\end{array}$} \\
\hline \multicolumn{5}{|c|}{ Mean value of CGPI=63.89 } \\
\hline \multicolumn{5}{|c|}{ Standard Deviation of CGPI=8.98 } \\
\hline Categories & Description & Classification & Value & $\begin{array}{l}\text { Count } \\
\text { of firms }\end{array}$ \\
\hline 1 & Excellent & $>$ Mean+1.5*SD & $(>=77)$ & 16 \\
\hline 2 & Matured & $\begin{array}{l}\text { Mean+0.5*SD to } \\
\text { Mean+1.5*SD }\end{array}$ & $(69-76)$ & 136 \\
\hline 3 & Optimum & $\begin{array}{l}\text { Mean-0.5SD to } \\
\text { Mean+0.5*SD }\end{array}$ & $(61-68)$ & 168 \\
\hline 4 & Fair & $\begin{array}{l}\text { Mean-1.5*SD to } \\
\text { Mean- } 0.5 * S D\end{array}$ & $(53-60)$ & 80 \\
\hline 5 & Poor & $<=$ Mean $-1.5 *$ SD & $<=52$ & 74 \\
\hline ource. A & ted from Sa & $(2012)$ & & \\
\hline
\end{tabular}

Table 5.3

INDUSTRY CATEGORIZATION

Capitaline database provides industry membership for the BSE 500C index constituents. Due to the large number of industries, to perform industry level analysis, more macro classification of industries is required. Here it is a mapping of the micro classification of industries available in Capitaline mapped to macro classification created by the author.

\begin{tabular}{|c|l|l|}
\hline Sl.No & \multicolumn{1}{|c|}{ Industry (Micro classification) } & $\begin{array}{c}\text { Industry (Macro } \\
\text { classification) }\end{array}$ \\
\hline \hline 1 & Construction, Infrastructure & Infrastructure \\
\hline
\end{tabular}




\begin{tabular}{|c|l|l|}
\hline & $\begin{array}{l}\text { Automobile, Chemical, Engineering, } \\
\text { Jewellery, Manufacturing, Packing, }\end{array}$ & \\
2 & $\begin{array}{l}\text { Paper, Pharmaceutical, Ship building, } \\
\text { Textile }\end{array}$ & Manufacturing \\
\hline \hline 3 & Metal, Mining, Petrochemical & Mining \&Refining \\
\hline & $\begin{array}{l}\text { Communication, Education, Finance, } \\
\text { Food and Beverages, Health and }\end{array}$ & \\
& $\begin{array}{l}\text { Hygiene, Hospitality, Information } \\
\text { Technology, Logistics, Media, Shipping, } \\
\text { Telecommunication, Travel and Tourism, }\end{array}$ & \\
\hline & Transportation & Services \\
\hline \hline 5 & Retail, Trading & Trading \\
\hline \hline Source: Author & \\
\hline
\end{tabular}

\section{TABLE 7.1}

\section{REGRESSION ANALYSIS OF CVA}

An Ordinary Least Squares Regression establishes a linear equation between CVA and multiple financial ratios as regressors. Variables for regression is identified maintaining the critieria on factor loading of 0.8 and above in Principal Component Analysis with Varimax Rotation. Subsequently, the significance of the regression statistics further refined the variables. The equation will act as the multi factor model for $\mathrm{VaR}$ estimation with Monte Carlo Simulation. The regressors and their formulae are as follows, EM ratio= Total assets/shareholder equity, $\mathrm{TIE}=\mathrm{EBIT} /$ Interest Expense, $\mathrm{OM}=\mathrm{EBIT} /$ Sales

CVA = 2824 - 17301 Equity Multiplier Ratio - 7.80 Times Interest Earned834 Operating margin

\begin{tabular}{|l|r|r|r|c|r|}
\hline \multicolumn{1}{|c|}{ Predictor } & \multicolumn{1}{c|}{ Coef } & SE Coef & \multicolumn{1}{c|}{ T } & P & \multicolumn{1}{c|}{ VIF } \\
\hline Constant & 2824 & 2932 & 0.96 & 0.34 & \\
\hline \hline Equity Multiplier Ratio & -17301.5 & 745 & -23.2 & 0.00 & 1.007 \\
\hline \hline Times Interest Earned & -7.8046 & 0.2264 & -34.5 & 0.00 & 1 \\
\hline Operating margin & -833.62 & 43.18 & -19.3 & 0.00 & 1.007 \\
\hline \hline
\end{tabular}

$\mathrm{S}=42813.4 \quad \mathrm{R}-\mathrm{Sq}=85.2 \% \quad \mathrm{R}-\mathrm{Sq}(\mathrm{adj})=85.1 \%$

Source: Author (Minitab

Output) 
TABLE 7.2

\section{Descriptive Statistics of RISK and CVA}

Enterprise risk is defined as the probability of finding lower CVA values beyond the historical median threshold when applied on the predicted CVA distribution from the multi factor model. Manually computed CVA values are also identically arranged and analysed. Measures of central tendency, measures of dispersion, data distribution properties are computed on the risk data clusters formed from the member firms in each CGPI categories.

\begin{tabular}{|l|r|r|r|r|r|}
\hline $\begin{array}{l}\text { RISK } \\
\text { Analysis }\end{array}$ & \multicolumn{1}{|c|}{ CAT1 } & \multicolumn{1}{c|}{ CAT2 } & \multicolumn{1}{c|}{ CAT3 } & \multicolumn{1}{c|}{ CAT4 } & \multicolumn{1}{c|}{ CAT5 } \\
\hline Mean & 99.15 & 66.32 & 72.94 & 77.68 & 84.52 \\
\hline $\begin{array}{l}\text { Standard } \\
\text { Error }\end{array}$ & 0.82 & 4.39 & 3.64 & 5.01 & 4.07 \\
\hline Median & 100.00 & 87.19 & 90.14 & 95.72 & 97.40 \\
\hline Mode & 100.00 & 100.00 & 100.00 & 100.00 & 100.00 \\
\hline $\begin{array}{l}\text { Standard } \\
\text { Deviation }\end{array}$ & 1.82 & 37.26 & 35.07 & 29.19 & 23.00 \\
\hline \hline Sample & & & & & \\
Variance & 3.32 & 1388.55 & 1230.02 & 852.31 & 529.15 \\
\hline Kurtosis & 4.97 & -1.05 & -0.33 & 0.14 & 3.81 \\
\hline Skewness & -2.23 & -0.72 & -1.13 & -1.16 & -1.87 \\
\hline Range & 4.11 & 99.95 & 99.96 & 95.53 & 96.80 \\
\hline Minimum & 95.89 & 0.05 & 0.04 & 4.47 & 3.20 \\
\hline Maximum & 100.00 & 100.00 & 100.00 & 100.00 & 100.00 \\
\hline Count & 5.00 & 72.00 & 93.00 & 34.00 & 32.00 \\
\hline CVA & & & & & \\
Analysis & & & & & \\
\hline Mean & 125228.68 & -92487.27 & -64606.56 & -108391.63 & -129037.74 \\
\hline Standard & & & & & \\
Error & 64030.68 & 26146.16 & 14966.56 & 34628.76 & 34293.19 \\
\hline Median & -13492.50 & -41511.90 & -26961.67 & -28859.40 & -21570.36 \\
\hline Mode & 0.00 & 0.00 & 0.00 & 0.00 & 0.00 \\
\hline SD & 212365.75 & 256178.99 & 163950.49 & 227075.96 & 224875.50 \\
\hline CV & -1.70 & -2.77 & -2.54 & -2.09 & -1.74 \\
\hline Kurtosis & 4.76 & 60.03 & 58.06 & 14.42 & 3.74 \\
\hline Skewness & -2.18 & -7.28 & -7.10 & -3.57 & -2.11 \\
\hline Range & 681640.10 & 2299783.68 & 1531498.21 & 1227652.09 & 924733.55 \\
\hline Minimum & - & - & & & -924733.55 \\
\hline
\end{tabular}




\begin{tabular}{|l|r|r|r|r|r|}
\hline & 681640.10 & 2299783.68 & 1531498.21 & 1227652.09 & \\
\hline Maximum & 0.00 & 0.00 & 0.00 & 0.00 & 0.00 \\
\hline Count & 11.00 & 96.00 & 120.00 & 43.00 & 43.00 \\
\hline
\end{tabular}

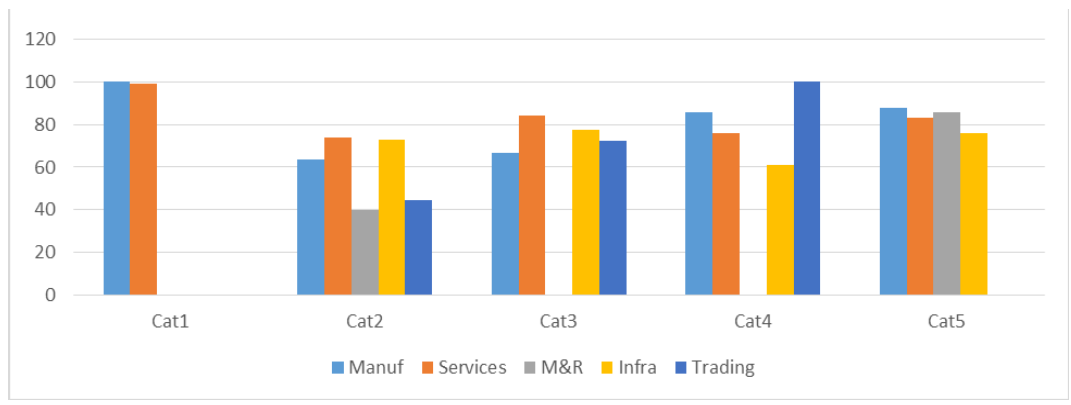

Fig 7.1 Graphical Analysis of Average Risk based on Categories (Industry level comparison)

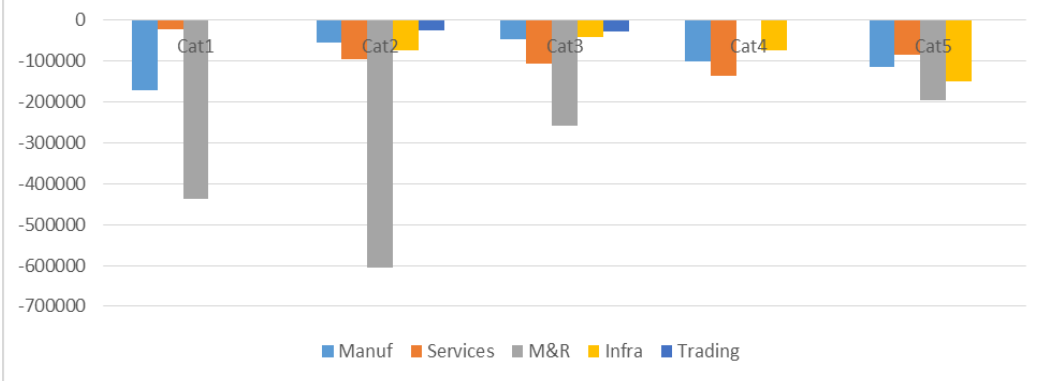

Fig 7.2 Graphical Analysis of Average CVA based on Categories (Industry level comparison)

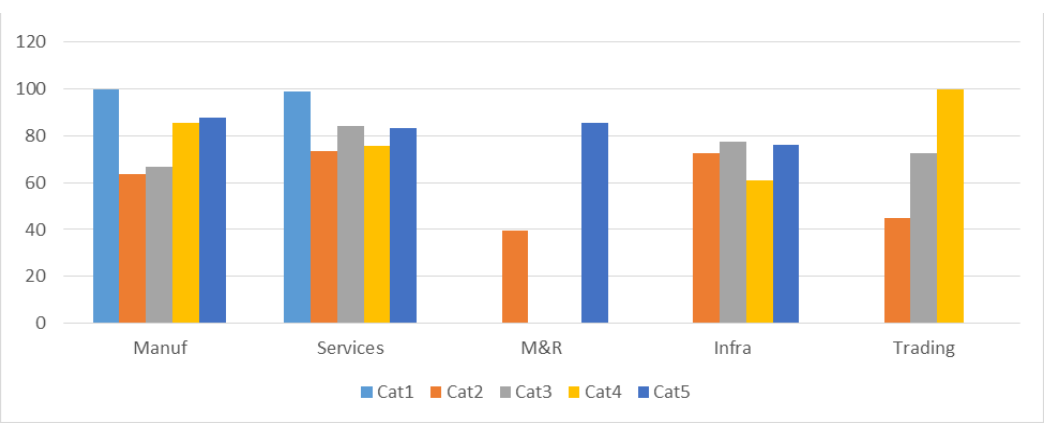

Fig 7.3 Graphical Analysis of Average Risk based on Industries (Industry level comparison) 


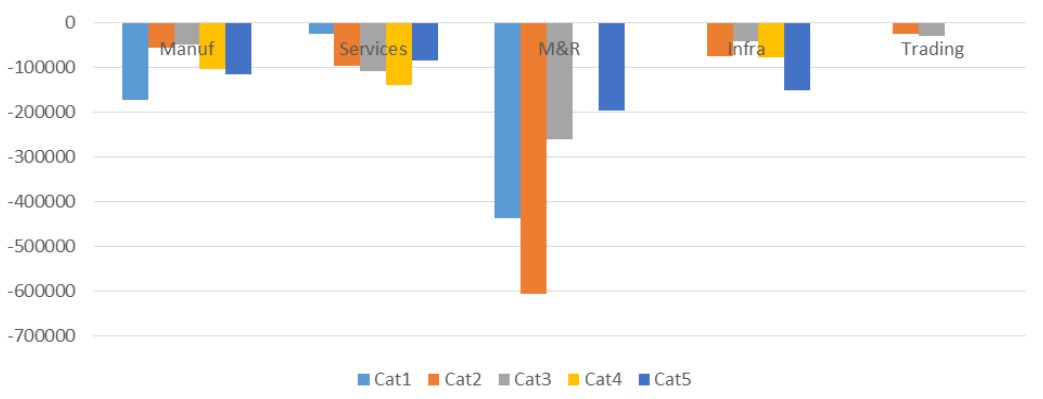

Fig 7.4 Graphical Analysis of Average CVA based on Industries

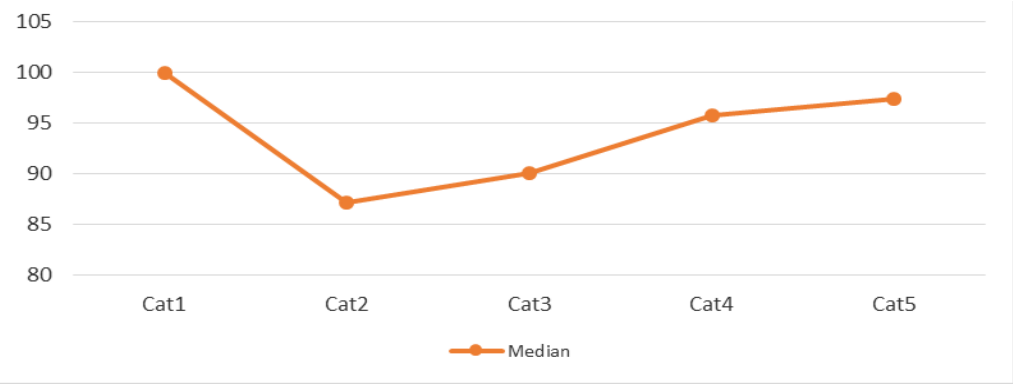

Fig 7.5 Graphical Analysis of Average Risk across categories

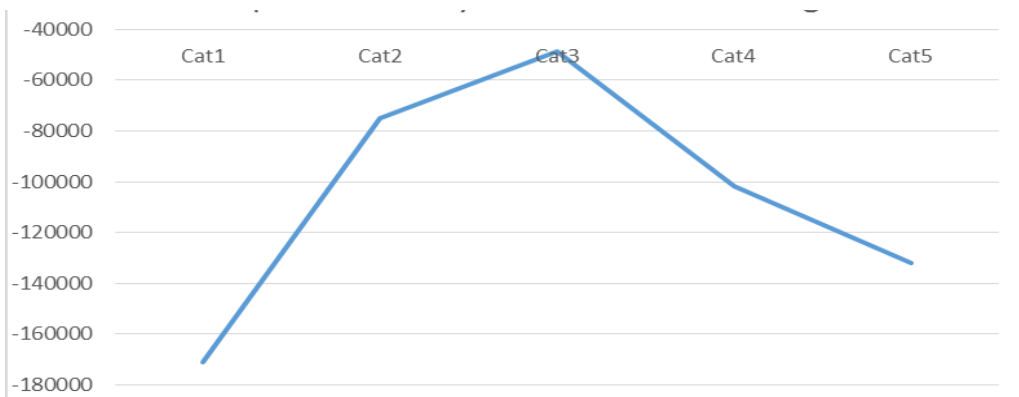

Fig 7.6 Graphical Analysis of CVA across categories 


\begin{tabular}{|c|c|c|c|}
\hline \multicolumn{4}{|c|}{ TABLE 7.3} \\
\hline \multicolumn{4}{|c|}{ CORRELATION ANALYSIS OF RISK AND CVA } \\
\hline \multicolumn{4}{|c|}{$\begin{array}{l}\text { CGPI, CVA and Risk values at the firm level were collected and } \\
\text { classified based on CGPI categories. Coefficient of correlation } \\
\text { was computed for all combinations at Category level to assess } \\
\text { the nature and strength of association existing among them. }\end{array}$} \\
\hline & CGPI Vs CVA & CGPI Vs RISK & CVA Vs RISK \\
\hline Cat1 & 0.22827 & 0.638803 & 0.538321 \\
\hline Cat2 & -0.14149 & 0.088217 & 0.270753 \\
\hline Cat3 & -0.35656 & -0.47302 & 0.359781 \\
\hline Cat4 & -0.34462 & -0.33799 & 0.574515 \\
\hline Cat5 & -0.42604 & -0.46408 & 0.704015 \\
\hline
\end{tabular}

Table 7.4 A Comparative Analysis of Risk Among Age Groups

\begin{tabular}{l}
$\begin{array}{l}\text { Risk is the probability of finding lower CVA than the historical median } \\
\text { threshold set on the predicted probability distribution of CVA. Does risk of } \\
\text { enterprises significantly vary with corporate age? To ascertain the } \\
\text { statistical truth, companies grouped under CGPI categories are classified } \\
\text { into age groups. Average and variance of risk of all the clusters are } \\
\text { computed. Using One-Way ANOVA, average is analysed. Null hypothesis } \\
\text { is Average risk of the age groups are equal and alternate hypothesis is } \\
\text { average risk of the age groups are significantly different. Similarly, } \\
\text { variances in risks are tested with Levene's test with Brown and Forsythe } \\
\text { modification in Panel B. }\end{array}$ \\
\hline \hline $\begin{array}{l}\text { RISK- } \\
\text { Mean }\end{array}$
\end{tabular}




\begin{tabular}{|l|r|r|r|r|r|l|}
\hline Total & 3292.804 & 19 & & & & \\
\hline RISK-SD & & & & & & \\
\hline Age & 1 & 2 & 3 & 4 & & \\
\hline Cat1 & 0 & 0 & 0 & 0.11 & & \\
\hline \hline Cat2 & 32.98 & 37.89 & 37.75 & 32.03 & & \\
\hline \hline Cat3 & 34.81 & 33.78 & 37.54 & 36.65 & & \\
\hline Cat4 & 28.13 & 24.21 & 41.21 & 24.65 & & \\
\hline \hline Cat5 & 28.35 & 22.3 & 22.7 & 6.9 & & \\
\hline ANOVA & & & & & & \\
\hline \hline $\begin{array}{l}\text { Source of } \\
\text { Variation }\end{array}$ & SS & df & MS & F & P-value & F crit \\
\hline \hline $\begin{array}{l}\text { Between } \\
\text { Groups }\end{array}$ & 54.11572 & 3 & 18.03857 & 0.125571 & 0.943595 & 3.238872 \\
\hline $\begin{array}{l}\text { Within } \\
\text { Groups }\end{array}$ & 2298.43 & 16 & 143.6519 & & & \\
\hline Total & 2352.546 & 19 & & & & \\
\hline
\end{tabular}

Table 7.5 A Comparative Analysis of Risk Among Industry Groups

Risk is the probability of finding lower CVA than the historical median threshold set on the predicted probability distribution of CVA. Does risk of enterprises significantly vary among industry groups?.To ascertain the statistical truth, companies grouped under CGPI categories are classified into industry wise clusters. Average risk and variance of all the clusters are computed and using One-Way ANOVA average is analysed. Null hypothesis is Average risk of the industry groups are equal and alternate hypothesis is average risk of the industry groups are significantly different. Similarly, variances are analysed with Levene's test with Brown and Forsythe modification in Panel B.

\begin{tabular}{|l|r|r|r|r|r|l|}
\hline $\begin{array}{l}\text { RISK- } \\
\text { Mean }\end{array}$ & & & & & & \\
\hline Industry & Manuf & Services & M\&R & Infra & Trading & \\
\hline \hline Cat1 & 100 & 98.94 & 0 & & & \\
\hline \hline Cat2 & 63.65 & 73.67 & 39.68 & 72.63 & 44.76 & \\
\hline Cat3 & 66.94 & 84.41 & 0 & 77.36 & 72.56 & \\
\hline \hline Cat4 & 85.61 & 75.8 & 0 & 61.2 & 100 & \\
\hline \hline Cat5 & 87.58 & 83.2 & 85.61 & 76.18 & 0 & \\
\hline ANOVA & & & & & & \\
\hline \hline $\begin{array}{l}\text { Source } \\
\text { of } \\
\text { Variatio } \\
\mathrm{n}\end{array}$ & SS & df & MS & F & P-value & F crit \\
\hline
\end{tabular}


Sajit Jacob

Does Corporate Governance Influence Enterprise Risk

\begin{tabular}{|c|c|c|c|c|c|c|}
\hline Between & 11428.7 & & 2857.19 & & 0.01635 & 2.92774 \\
\hline Groups & 7 & 4 & 3 & 4.047218 & 3 & 4 \\
\hline Within & 12707.3 & & 705.964 & & & \\
\hline Groups & 6 & 18 & 6 & & & \\
\hline Total & $\begin{array}{r}24136.1 \\
3\end{array}$ & 22 & & & & \\
\hline \multicolumn{7}{|l|}{ RISK-SD } \\
\hline Industry & Manuf & Services & M\&R & Infra & Trading & \\
\hline Cat1 & 0 & 2.03 & 0 & 0 & 0 & \\
\hline Cat2 & 39.17 & 31.4 & 47.27 & 46.23 & 63.04 & \\
\hline Cat3 & 38.5 & 28 & & 28.21 & 29 & \\
\hline Cat4 & 24.9 & 29.96 & 0 & 34.7 & 0 & \\
\hline Cat5 & 26.64 & 21.81 & 24.93 & 12.96 & 0 & \\
\hline \multicolumn{7}{|l|}{ ANOVA } \\
\hline $\begin{array}{l}\text { Source } \\
\text { of } \\
\text { Variatio } \\
\mathrm{n}\end{array}$ & SS & $\mathrm{df}$ & MS & $\mathrm{F}$ & P-value & F crit \\
\hline Between & 402.311 & & 100.577 & & 0.79842 & 2.86608 \\
\hline Groups & 6 & 4 & 9 & 0.411252 & 4 & 1 \\
\hline $\begin{array}{l}\text { Within } \\
\text { Groups }\end{array}$ & $\begin{array}{r}4891.30 \\
4\end{array}$ & 20 & $\begin{array}{r}244.565 \\
?\end{array}$ & & & \\
\hline & & & & & & \\
\hline Total & $\begin{array}{r}5293.61 \\
6\end{array}$ & 24 & & & & \\
\hline
\end{tabular}

Table 7.6 A Comparative Analysis Risk Among Size Groups

Risk is the probability of finding lower CVA than the historical median threshold set on the predicted probability distribution of CVA. Does risk of enterprises significantly vary among enterprise size groups?.To ascertain the statistical truth, companies grouped under CGPI categories are classified into enterprise size clusters. Average risk and variances of all the clusters are computed and using One-Way ANOVA, average is analysed. Null hypothesis is Average risk of the size groups are equal and alternate hypothesis is average risk of the size groups are significantly different. Similarly, variances are analysed with Levene's test with Brown and Forsythe modification in Panel B.

\begin{tabular}{|l|r|r|r|r|r|l|}
\hline $\begin{array}{l}\text { RISK- } \\
\text { Mean }\end{array}$ & & & & & & \\
\hline MrktCap & 1 & 2 & 3 & 4 & & \\
\hline
\end{tabular}




\begin{tabular}{|c|c|c|c|c|c|c|}
\hline Cat1 & 95.89 & 100 & 100 & 99.93 & & \\
\hline Cat2 & 74.97 & 48.24 & 75.35 & 78.09 & & \\
\hline Cat3 & 69.4 & 76.02 & 72.36 & 74.07 & & \\
\hline Cat4 & 74.12 & 88.49 & 64.61 & 85.84 & & \\
\hline Cat5 & 76.36 & 85.24 & 86.65 & 95.81 & & \\
\hline \multicolumn{7}{|l|}{ ANOVA } \\
\hline $\begin{array}{l}\text { Source of } \\
\text { Variation }\end{array}$ & SS & $\mathrm{df}$ & MS & $\mathrm{F}$ & P-value & F crit \\
\hline $\begin{array}{l}\text { Between } \\
\text { Groups }\end{array}$ & 222.8636 & 3 & 74.28785 & 0.371747 & 0.774482 & 3.238872 \\
\hline $\begin{array}{l}\text { Within } \\
\text { Groups }\end{array}$ & 3197.352 & 16 & 199.8345 & & & \\
\hline Total & 3420.215 & 19 & & & & \\
\hline \multicolumn{7}{|l|}{ RISK-SD } \\
\hline MrktCap & 1 & 2 & 3 & 4 & & \\
\hline Cat1 & 0 & 0 & 0 & 0.11 & & \\
\hline Cat2 & 32.98 & 37.89 & 37.75 & 32.03 & & \\
\hline Cat3 & 33.64 & 36.1 & 35.81 & 37.46 & & \\
\hline Cat4 & 28.13 & 20.22 & 38.59 & 18.25 & & \\
\hline Cat5 & 28.35 & 22.3 & 22.7 & 6.9 & & \\
\hline \multicolumn{7}{|l|}{ ANOVA } \\
\hline $\begin{array}{l}\text { Source of } \\
\text { Variation }\end{array}$ & SS & Df & MS & F & P-value & F crit \\
\hline $\begin{array}{l}\text { Between } \\
\text { Groups }\end{array}$ & 59.62738 & 3 & 19.87579 & 0.155883 & 0.924359 & 3.238872 \\
\hline $\begin{array}{l}\text { Within } \\
\text { Groups }\end{array}$ & 2040.073 & 16 & 127.5045 & & & \\
\hline Total & 2099.7 & 19 & & & & \\
\hline
\end{tabular}

\section{Table 7.7 A Comparative Analysis Of CCA among Age Groups}

CVA is the excess operating cash flow generated beyond the operating cash flow demand, computed manually from the accounting figures. Does CVA of enterprises significantly vary with corporate age? To ascertain the statistical truth, companies grouped under CGPI categories are classified into age groups. Average risk and variances of all the clusters are computed. Using One-Way ANOVA, means are analysed. While variances are analysed, using Levene's test with Brown and Forsythe Modification in Panel B.

\section{CVA-}

Mean

52 


\begin{tabular}{|c|c|c|c|c|c|c|}
\hline Age & 1 & 2 & 3 & 4 & & \\
\hline Cat1 & 6746.25 & -29268.4 & -95809.3 & -186498 & & \\
\hline Cat2 & -60860.3 & -46347.1 & -210813 & -72021.6 & & \\
\hline Cat3 & -62090.5 & -38665 & -59270.3 & -107198 & & \\
\hline Cat4 & -116693 & -19585.6 & -133309 & -188959 & & \\
\hline Cat5 & -85814.4 & -168528 & -136675 & -132607 & & \\
\hline \multicolumn{7}{|l|}{ ANOVA } \\
\hline $\begin{array}{l}\text { Source of } \\
\text { Variation }\end{array}$ & SS & Df & MS & $\mathrm{F}$ & $\begin{array}{l}\mathrm{P}- \\
\text { value }\end{array}$ & $\begin{array}{l}\mathrm{F} \\
\text { crit }\end{array}$ \\
\hline $\begin{array}{l}\text { Between } \\
\text { Groups }\end{array}$ & 24934896664 & 3 & 8311632221 & 2.874531 & 0.0688 & 3.24 \\
\hline $\begin{array}{l}\text { Within } \\
\text { Groups }\end{array}$ & 46263586844 & 16 & 2891474178 & & & \\
\hline Total & 71198483509 & 19 & & & & \\
\hline \multicolumn{7}{|l|}{ CVA-SD } \\
\hline Age & 1 & 2 & 3 & 4 & & \\
\hline Cat1 & 9540.638 & 41391.77 & 135494.8 & 250472 & & \\
\hline Cat2 & 93324.72 & 36240.24 & 522575.9 & 82204.3 & & \\
\hline Cat3 & 142388 & 51063 & 81649.16 & 300488.9 & & \\
\hline Cat4 & 198648.9 & 13843.59 & 197953 & 377261.4 & & \\
\hline Cat5 & 195569.6 & 226004.3 & 267584.8 & 228316.5 & & \\
\hline \multicolumn{7}{|l|}{ ANOVA } \\
\hline $\begin{array}{l}\text { Source of } \\
\text { Variation }\end{array}$ & SS & Df & MS & $\mathrm{F}$ & $\begin{array}{l}\mathrm{P} \text { - } \\
\text { value }\end{array}$ & $\begin{array}{l}\text { F } \\
\text { crit }\end{array}$ \\
\hline $\begin{array}{l}\text { Between } \\
\text { Groups }\end{array}$ & 13549570992 & 3 & 4516523664 & 0.622295 & 0.6108 & 3.24 \\
\hline $\begin{array}{l}\text { Within } \\
\text { Groups }\end{array}$ & $1.16126 \mathrm{E}+11$ & 16 & 7257846381 & & & \\
\hline Total & "1.29675E+11 & 19 & & & & \\
\hline
\end{tabular}

Table 7.8 A Comparative Analysis of CCA Among Industry Groups

CVA is the excess operating cash flow generated beyond the operating cash flow demand, computed manually from the accounting figures. Does CVA of enterprises significantly vary with industry? To ascertain the statistical truth, companies grouped under CGPI categories are classified into industry groups. Average risk and variances of all the clusters are computed. Using One-Way ANOVA, means are analysed. While variances are analysed, using Levene's test with Brown and Forsythe Modification in Panel B.

\begin{tabular}{|l|l|l|l|l|l|l|}
\hline $\begin{array}{l}\text { CVA- } \\
\text { Mean }\end{array}$ & & & & & & \\
\hline Industry & Manuf & Service & M\&R & Infra & Tradin & \\
\hline
\end{tabular}




\begin{tabular}{|c|c|c|c|c|c|c|}
\hline & & $\mathrm{s}$ & & & $\mathrm{g}$ & \\
\hline Cat1 & -170922 & $23201.9^{-}$ & -436629 & & & \\
\hline Cat2 & -54898.9 & 96193.7 & -605506 & $\begin{array}{r}- \\
74820.6\end{array}$ & -24648 & \\
\hline Cat3 & -48767.8 & -106723 & -259425 & $\begin{array}{r}- \\
40740.7 \\
\end{array}$ & 28699. & \\
\hline Cat4 & -101615 & -137513 & & $\begin{array}{r}- \\
75708.7 \\
\end{array}$ & & \\
\hline Cat5 & -114938 & 84672.1 & -195100 & -149458 & & \\
\hline \multicolumn{7}{|l|}{ ANOVA } \\
\hline $\begin{array}{l}\text { Source of } \\
\text { Variation } \\
\end{array}$ & SS & $\mathrm{df}$ & MS & $\mathrm{F}$ & $\begin{array}{r}\mathrm{P}- \\
\text { value }\end{array}$ & F crit \\
\hline Between & $2.78388 \mathrm{E}+$ & & 695969403 & & 0.00097 & 3.05556 \\
\hline Groups & 11 & 4 & 22 & 8.29023 & 8 & 8 \\
\hline $\begin{array}{l}\text { Within } \\
\text { Groups }\end{array}$ & $\begin{array}{r}1.25926 \mathrm{E}+ \\
11 \\
\end{array}$ & 15 & $\begin{array}{r}839505549 \\
8 \\
\end{array}$ & & & \\
\hline Total & $\begin{array}{r}4.04314 \mathrm{E}+ \\
11 \\
\end{array}$ & 19 & & & & \\
\hline \multicolumn{7}{|l|}{ CVA-SD } \\
\hline Industry & Manuf & $\begin{array}{r}\text { Service } \\
\mathrm{s} \\
\end{array}$ & $M \& R$ & Infra & $\begin{array}{r}\text { Tradin } \\
\mathrm{g} \\
\end{array}$ & \\
\hline Cat1 & 230801.5 & $\begin{array}{r}33365.2 \\
8 \\
\end{array}$ & 346497.5 & 0 & 0 & \\
\hline Cat2 & 63334.12 & 181183 & 1129695 & $\begin{array}{r}113928 . \\
2 \\
\end{array}$ & $\begin{array}{r}34857.5 \\
9 \\
\end{array}$ & \\
\hline Cat3 & 61116.91 & $\begin{array}{r}299879 . \\
1 \\
\end{array}$ & 0 & $\begin{array}{r}44245.9 \\
8 \\
\end{array}$ & $\begin{array}{r}33019.1 \\
9 \\
\end{array}$ & \\
\hline Cat4 & 162132.4 & $\begin{array}{r}329094 . \\
4 \\
\end{array}$ & 0 & $\begin{array}{r}75595.2 \\
3 \\
\end{array}$ & 0 & \\
\hline Cat5 & 226904.4 & $\begin{array}{r}219632 . \\
6 \\
\end{array}$ & 220595 & $\begin{array}{r}267785 . \\
4 \\
\end{array}$ & 0 & \\
\hline \multicolumn{7}{|l|}{ ANOVA } \\
\hline $\begin{array}{l}\text { Source of } \\
\text { Variation } \\
\end{array}$ & SS & $\mathrm{df}$ & MS & $\mathrm{F}$ & $\begin{array}{r}\mathrm{P}- \\
\text { value }\end{array}$ & F crit \\
\hline Between & $2.39577 \mathrm{E}+$ & & 598943312 & 2.16057 & 0.11070 & 2.86608 \\
\hline Groups & 11 & 4 & 06 & 1 & 3 & 1 \\
\hline $\begin{array}{l}\text { Within } \\
\text { Groups }\end{array}$ & $\begin{array}{r}5.54431 \mathrm{E}+ \\
11 \\
\end{array}$ & 20 & $\begin{array}{r}277215261 \\
80 \\
\end{array}$ & & & \\
\hline Total & $\begin{array}{r}7.94008 \mathrm{E}+ \\
11 \\
\end{array}$ & 24 & & & & \\
\hline
\end{tabular}


Table 7.9 A Comparative Analysis CCA Among Size Groups

CVA is the excess operating cash flow generated beyond the operating cash flow demand, computed manually from the accounting figures. Does CVA of enterprises significantly vary with enterprise size?.To ascertain the statistical truth, companies grouped under CGPI categories are classified into sizey groups. Average risk and variances of all the clusters are computed. Using One-Way ANOVA, means are analysed. While variances are analysed, using Levene;s test with Brown and Forsythe Modification in Panel B.

\begin{tabular}{|c|c|c|c|c|c|c|}
\hline $\begin{array}{l}\text { CVA- } \\
\text { Mean }\end{array}$ & & & & & & \\
\hline MrktCap & 1 & 2 & 3 & 4 & & \\
\hline Cat1 & -6746.25 & -29268.4 & -95809.3 & -222774 & & \\
\hline Cat2 & -60860.3 & -46347.1 & -205626 & -70993.3 & & \\
\hline Cat3 & -62046.6 & -43267.8 & -54138.2 & -111665 & & \\
\hline Cat4 & -116693 & -18688.6 & -120495 & -190900 & & \\
\hline Cat5 & -85814.4 & -168528 & -136675 & -132607 & & \\
\hline \multicolumn{7}{|l|}{ ANOVA } \\
\hline $\begin{array}{l}\text { Source of } \\
\text { Variation }\end{array}$ & SS & $\mathrm{df}$ & MS & $\mathrm{F}$ & P-value & F crit \\
\hline $\begin{array}{l}\text { Between } \\
\text { Groups }\end{array}$ & $2.62 \mathrm{E}+10$ & 3 & $8.72 \mathrm{E}+09$ & 2.858954 & 0.06973 & 3.238871517 \\
\hline $\begin{array}{l}\text { Within } \\
\text { Groups }\end{array}$ & $4.88 \mathrm{E}+10$ & 16 & $3.05 E+09$ & & & \\
\hline Total & $7.5 \mathrm{E}+10$ & 19 & & & & \\
\hline \multicolumn{7}{|l|}{ CVA-SD } \\
\hline MrktCap & 1 & 2 & 3 & 4 & & \\
\hline Cat1 & 9540.638 & 41391.77 & 135494.8 & 289408.9 & & \\
\hline Cat2 & 93324.72 & 36240.24 & 510561.9 & 83807.92 & & \\
\hline Cat3 & 149401.6 & 60834.61 & 77380.85 & 306102.8 & & \\
\hline Cat4 & 198648.9 & 14551.64 & 178629 & 400093.2 & & \\
\hline Cat5 & 195569.6 & 226004.3 & 267584.8 & 228316.5 & & \\
\hline \multicolumn{7}{|l|}{ ANOVA } \\
\hline $\begin{array}{l}\text { Source of } \\
\text { Variation }\end{array}$ & SS & $\mathrm{df}$ & MS & $\mathrm{F}$ & P-value & F crit \\
\hline $\begin{array}{l}\text { Between } \\
\text { Groups }\end{array}$ & $1.26 \mathrm{E}+10$ & 3 & 4.19E+09 & 0.523066 & 0.672572 & 3.238871517 \\
\hline $\begin{array}{l}\text { Within } \\
\text { Groups }\end{array}$ & $1.28 \mathrm{E}+11$ & 16 & $8.01 \mathrm{E}+09$ & & & \\
\hline Total & $1.41 \mathrm{E}+11$ & 19 & & & & \\
\hline
\end{tabular}


Table 7.10 A Comparative Analysis of Proportion of Zero Risk Companies Among Industries

Where do we see more risk free companies? Proportion of zero risk companies at industry level within CGPI category data collated and analysed with oneway ANOVA for the hypothesis that there is no significant difference in the proportion of risk free companies across different industries.

\begin{tabular}{|l|r|r|r|r|r|r|}
\hline & Infra & Manuf & M\&R & Services & & \\
\hline Cat1 & 0 & 0.003185 & 0.006369 & 0.009554 & & \\
\hline Cat2 & 0.012739 & 0.038217 & 0.003185 & 0.022293 & & \\
\hline Cat3 & 0.009554 & 0.050955 & 0.003185 & 0.025478 & & \\
\hline Cat4 & 0.003185 & 0.019108 & 0 & 0.006369 & & \\
\hline Cat5 & 0.003185 & 0.015924 & 0.015924 & 0 & & \\
\hline ANOVA & & & & & & \\
\hline Source & SS & Df & MS & F & P-value & F crit \\
\hline Rows & 0.000922 & 4 & 0.000231 & 1.625745 & 0.258636 & 3.837853 \\
\hline $\begin{array}{l}\text { Column } \\
\text { s }\end{array}$ & 0.001002 & 2 & 0.000501 & 3.532777 & 0.07951 & 4.45897 \\
\hline Error & 0.001135 & 8 & 0.000142 & & & \\
\hline Total & 0.003059 & 14 & & & & \\
\hline \hline
\end{tabular}

Table 7.11 A Comparative Analysis of Proportion of Zero Risk Companies Among Age Groups

Where do we see more risk free companies? Proportion of zero risk companies at different enterprise age level data within CGPI categories collated and analysed with one-way ANOVA for the hypothesis that there is no significant difference in the proportion of risk free companies across different age groups.

\begin{tabular}{|l|c|c|c|c|c|c|}
\hline & 1 & 2 & 3 & 4 & & \\
\hline Cat1 & 0.003185 & 0.003185 & 0.003185 & 0.009554 & & \\
\hline Cat2 & 0.009554 & 0.006369 & 0.022293 & 0.038217 & & \\
\hline Cat3 & 0.022293 & 0.015924 & 0.015924 & 0.035032 & & \\
\hline Cat4 & 0.009554 & 0.003185 & 0.009554 & 0.006369 & & \\
\hline Cat5 & 0.003185 & 0.009554 & 0.012739 & 0.009554 & & \\
\hline ANOVA & & & & & & \\
\hline Source & SS & Df & MS & F & P-value & F crit \\
\hline Rows & 0.000842 & 4 & 0.000211 & 3.869565 & 0.049028 & 3.837853 \\
\hline Columns & 0.000369 & 2 & 0.000185 & 3.391304 & 0.085774 & 4.45897 \\
\hline Error & 0.000435 & 8 & $5.44 \mathrm{E}-05$ & & & \\
\hline \hline Total & 0.001647 & 14 & & & & \\
\hline \hline
\end{tabular}


Table 7.12 A Comparative Analysis of Proportion of Zero Risk Companies Among Size Groups

Where do we see more risk free companies? Proportion of zero risk companies at different enterprise size level data within CGPI categories collated and analysed with one-way ANOVA for the hypothesis that there is no significant difference in the proportion of risk free companies across different size groups.

\begin{tabular}{|l|c|c|c|c|c|c|}
\hline MktCap & 1 & 2 & 3 & 4 & & \\
\hline Cat1 & 0.003185 & 0.003185 & 0.003185 & 0.009554 & & \\
\hline Cat2 & 0.009554 & 0.006369 & 0.025478 & 0.035032 & & \\
\hline \hline Cat3 & 0.022293 & 0.015924 & 0.015924 & 0.035032 & & \\
\hline Cat4 & 0.009554 & 0.003185 & 0.009554 & 0.006369 & & \\
\hline Cat5 & 0.003185 & 0.009554 & 0.012739 & 0.009554 & & \\
\hline \hline ANOVA & & & & & & \\
\hline \hline Source & SS & Df & MS & F & P-value & F crit \\
\hline Rows & 0.000842 & 4 & 0.000211 & 3.869565 & 0.049028 & 3.837853 \\
\hline \hline Column & & & & & & \\
s & 0.000369 & 2 & 0.000185 & 3.391304 & 0.085774 & 4.45897 \\
\hline Error & 0.000435 & 8 & $5.44 \mathrm{E}-05$ & & & \\
\hline Total & 0.001647 & 14 & & & & \\
\hline
\end{tabular}

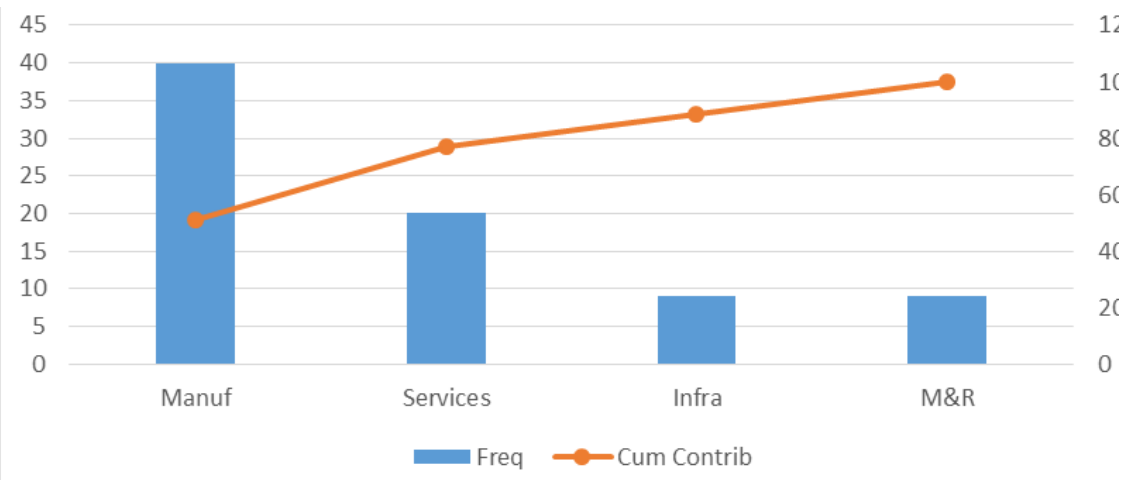

Fid 7.7 Industry based Pareto Analysis of Zero Risk Population 


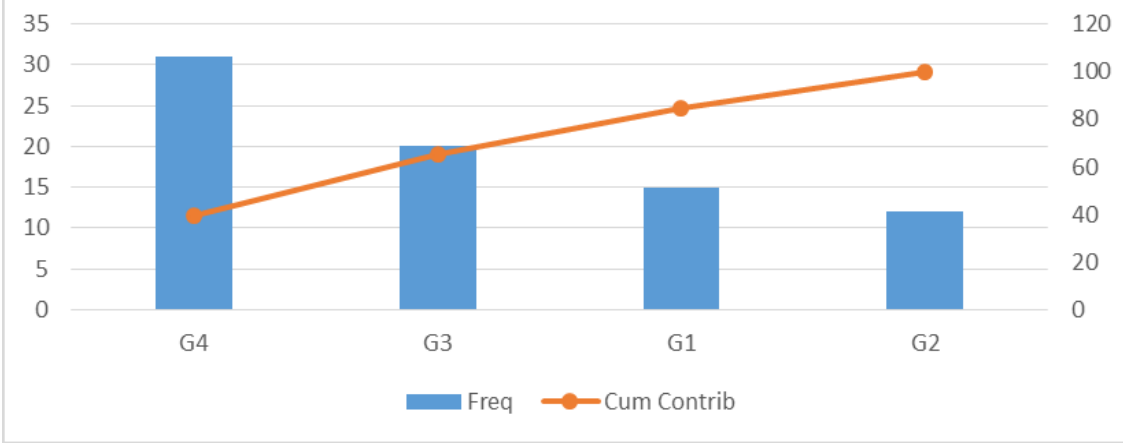

Fig 7.8 Market Cap based Pareto Analysis of Zero Risk Population

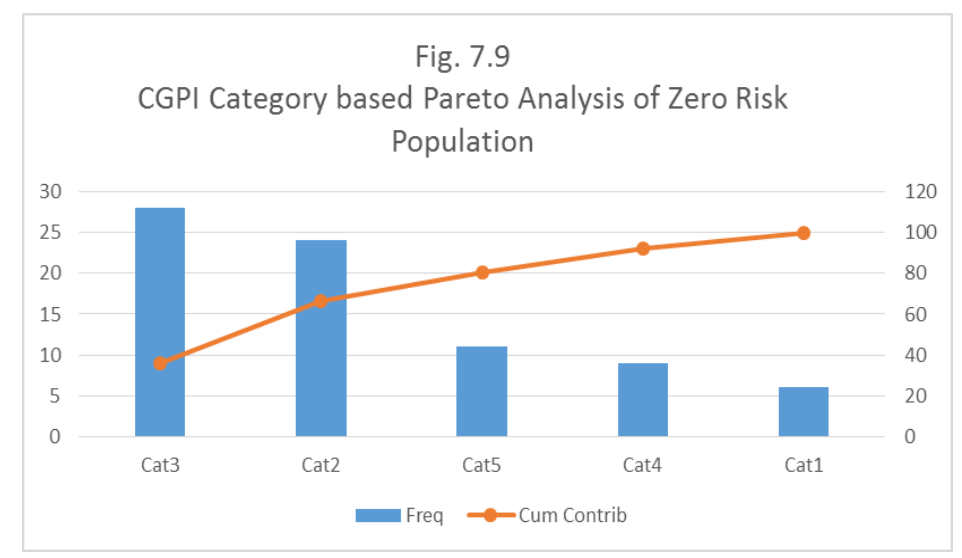

Fig 7.9 CGPI based Pareto Analysis of Zero Risk Population 